\title{
REPRESENTASI GAMBAR PERINGATAN KESEHATAN \\ PADA KEMASAN ROKOK \\ (Analisis Semiotika Roland Barthes Berdasarkan Peraturan Menteri Kesehatan \\ No 28 Tahun 2013)
}

Oleh:

\author{
M. SOLIKUL HUDA, LINDA ASTUTI, BAYU RISDIYANTO \\ Program Studi Ilmu Komunikasi Fakultas Ilmu-Ilmu Sosial \\ Universitas Dehasen Bengkulu
}

\begin{abstract}
The Government Regulation No. 109 of 2012 on Security of materials containing additives in the form of tobacco products for health in value are no longer effective. In accordance with the provisions of the Government through the Minister of Health issued Regulation No. 28 of 2013 on the inclusion of health warning and health information on tobacco products in the form of images and writings. In the Minister of Health Regulation No. 28 of 2013, there are five images that must be applied to all Tobacco Products such as smoking pictures caused by oral cancer, smoking pictures kill you, smoking pictures caused by oral cancer, smoking pictures near the children are dangerous for them and smoking pictures caused by lung cancer and chronic bronchitis. The aim of this study is to find out the meaning of health warning images in cigarette packaging. It is the meaning of denotation, connotation and myth as revealed by Roland Barthes. The writer collected data from primary and secondary data and analyzed data by using Roland Barthes semiotics. This study uses a qualitative method.The results of this study can be concluded that the denotative meaning of health warning picture in government regulation No. 28 of 2013 is a form of warning in the form of a call about the consequences and appearance of the symptoms caused dangerous diseases, death, and distress for children caused by smoking. The connotative meaning built up is due to the neglect of the importance of warning and the call of dangerous diseases can lead to cancer, death, and harm to people around smokers. While the myths formed from the five images of health warning is a form of threat to smokers for the impact that occurred to immediately leave the habit and more concerned about his life and health.
\end{abstract}

Keywords: denotation, connotation, myths, drawings and cigarettes

\section{PENDAHULUAN}

Peringatan di bungkus rokok sudah di terapkan dalam bentuk tulisan sejak tahun 1999 melalui Peraturan Pemerintah No 8 Tahun 1999 tentang Pengamanan Rokok Bagi Kesehatan. Informasi tertulis ini terbukti tidak efektif, studi pusat penelitian kesehatan Universitas Indonesia Tahun 2007 menunjukan sebanyak 47\% masyarakat tidak mempedulikan isi peringatan karena tidak terbukti, 26\% tidak termotivasi berhenti merokok dan 20\% mengatakan tulisan terlalu kecil dan tidak terbaca. Berdasarkan hasil penelitian pusat kesehatan Universitas Indonesia Fakultas Kesehatan Masyarakat diketahui bahwa peringatan bahaya merokok dalam bentuk teks tidak lagi efektif karena perokok tidak lagi percaya terhadap kata-kata tersebut dikarenakan tidak adanya bukti nyata dari peringatan tersebut. (http://www.harian.haluan.com,di aksestanggal 16 Juli 2017Jam 17:05 Wib).

Peredaran rokok yang semakin tumbuh dari tahun ke tahun dengan tingkat konsumen yang tidak terkendali dari kaum tua, pemuda hingga merambah ke anakanak usia remaja membuat orang tua dan 
pemerintah sangat prihatin. Dari fenomena tersebut pemerintah membuat sebuah peraturan mengenai produk tembakau yang diatur didalam Undang-Undang Nomor 109 Tahun 2012 tentang Pengamanan Bahan yang Mengandung Zat Adiktif Berupa Produk Tembakau Bagi Kesehatan yang tertuang dalam paragraf kesembilan yang berbunyi "Masyarakat berhak mendapatkan informasi dan- peringatan yang jelas dan benar atas dampak yang ditimbulkan akibat merokok. Walaupun lebih dari $90 \%$ (sembilan puluh persen) masyarakat pernah membaca peringatan kesehatan berbentuk tulisan di bungkus rokok, hampir separuhnya tidak percaya dan 26\% (dua puluh enam persen) tidak termotivasi berhenti merokok. Studi di berbagai negara membuktikan peringatan tertulis yang disertai gambar lebih efektif daripada hanya berbentuk tulisan saja. Oleh karena itu, pesan kesehatan pada kemasan rokok wajib dicantumkan dalam bentuk gambar dan tulisan untuk meningkatkan kesadaran perokok dan bukan perokok akan bahayanya rokok bagi kesehatan. Agar efektif, peringatan kesehatan harus mudah dilihat, relevan, dan mudah diingat serta menggambarkan aspek yang perlu diketahui semua orang”. Peraturan Pemerintah ini secara resmi ditandatangani oleh Presiden Susilo Bambang Yudhoyono pada 24 Desember 2014.

Menindak lanjuti peratuaran pemerintah No 109 Tahun 2012 disebut bahwa ketentuan lebih lanjut mengenai gambar dan tulisan peringatan kesehatan sebagaimana di maksud dalam pasal 14 dan pasal 15 diatur dalam peraturan menteri setelah berkoordinasi dengan menteri yang menyelenggarakan urusan pemerintah di bidang keuangan. Sesuai amanat inilah kemudian menteri kesehatan menerbitkan peraturan No 28 Tahun 2013 tentang Pencantuman Peringatan Kesehatan dan Informasi Kesehatan Pada Produk Tembakau. (Peraturan Pemerintah Republik Indonesia Nomor 109 Tahun 2012, Tentang Pengamanan Bahan Yang
Mengandung Zat Adiktif Berupa Produk Tembakau Bagi Kesehatan).

Peraturan Menteri Kesehatan Nomor 28 Tahun 2013 tentang Pencantuman Gambar Peringatan Kesehatan Pada Kemasan Rokok merupakan program pemerintah Indonesia yang bertujuan memberikan informasi bagi masyarakat tentang bahaya merokok dan juga merupakan upaya pendidikan kesehatan yang dinilai efektif oleh pemerintah Indonesia karena dapat meningkatkan kesadaran masyarakat akan dampak rokok terhadap kesehatan. Peraturan ini mewajibkan para produsen rokok menampilkan lima gambar peringatan bahaya akibat mengkonsumsi rokok pada setiap kemasan produk rokok.

Sejak diberlakukanya Peraturan Menteri Kesehatan (Permenkes) No 28 Tahun 2013 pada 1 April 2013 yang di terapkan pada tanggal 24 Juni 2014, pada kenyataanya jumlah perokok di Indonesia tidak kunjung berkurang hal ini mengacu pada data yang di sajikan oleh Kementrian Perindustrian Bab II Lampiran Peraturan Menteri Perindustrian No 63/IND/PER/8/2015 tentang Road Map Produksi Industri Tembakau Tahun 20152020 sebagai berikut:

a. Terjadinya pasokan tembakau dan cengkeh untuk kebutuha industri tembakau.

b. Terdapat pertumbuhan produksi rokok pada kisaran 5-7,4\% pertahun.

c. Meningkatnya nilai ekspor hasil tembakau.

d. Meningkatnya kemitraan antara produsen Rokok dengan petani tembakau yang saling menguntungkan.

e. Terwujudnya kebijakan cukai dan pajak yang terencana sesuai kondsi perekonomian dan kemampuan industri tembakau .

f. Pengembangan kapasitas dalam rangka pendalaman struktur industri tembakau.

(http://www.101.255.58.243/files/refo biro/integritas/Permenperin_No.63_2 
015_1.pdf. diakses pada 6 September 2017, Pukul 20:22).

Selain itu juga Dewan Penasehat Komisi Nasional (Komnas) pengendalian tembakau Dr. Kartono Muhammad menjelaskan kepada wartawan media Hidayatullah, dalam wawancaranya Dr. Kartono Muhammad menngatakan "Kalau diukur dari kepatuhan pabrik rokok memasang gambar peringatan itu sudah hampir 100 persen, tetapi kalau efektivitas pengaruhnya kepada pecandu rokok biarpun ada gambar- peringatan itu tidak berpengaruh sama sekali, penurunan jumlah produksi rokok nggak ada. Justru yang ada kenaikan, dan jumlah produksi rokok juga belum menurun saat ini".

Dari data-data diatas bisa di simpulkan bahwa semakin tingginya tingkat produksi dan meningkatnya nilai ekspor hasil tembakau maka semakin tinggi juga jumlah pengkonsumsi rokok sehingga gambar dan tulisan peringatan kesehatan berdasarkan Permenkes No 28 Tahun 2013 yang ada saat ini masih belum efektif. Pencantuman gambar peringatan bahaya merokok pada kemasan rokok tidak berpengaruh besar pada konsumen rokok yang ada di Indonesia untuk tetap merokok bahkan konsumen rokokpun sering kali mengabaikan peringatan tersebut. Dengan demikian penulis tertarik untuk menganalisis Gambar Peringatan Kesehatan Pada Kemasan Rokok dengan menggunakan Analisis Semiotika Roland Barthes karna penulis ingin mengetahui makna apa saja yang terkandung dalam 5 (Lima) gambar yang tercantum pada kemasan rokok berdasarkan Permenkes No 28 Tahun 2013 dengan harapan bisa menjadi suatu pencegahan untuk perokok pemula dan bisa mengurangi angka pecandu rokok setelah mengetahui makna gambar tersebut.

Penelitian ini melibatkan pemikiran semiotika Roland Barthes, untuk mengembangkan pemikiran semiotika miliknya menjadi tiga tingkatan yaitu Denotasi, Konotasi dan Mitos. Roland Barthes adalah penerus pemikiran
Saussure, perbedaan pemikiran Saussure dan Roland Barthes, meskipun Roland Barthes menggunakan istilah signifiersignified yang di usung dari Saussure, Roland Barthes juga melihat aspek lain dari penandaan yaitu Mitos- yang menandai suatu masyarakat. Analisis semiotika di rasa sebagai metode yang paling tepat untuk meneliti makna di balik visual atau gambar. Melalui analisis semiotika Roland Barthes ini lah penelitian akan mampu memahami sistem dan makna yang terdapat pada gambar peringatan kesehatan dalam Permenkes No 28 Tahun 2013 di kemasan rokok.

Berdasarkan permasalahan di atas maka tujuan dari penelitian ini adalah sebagai berikut:

1. Untuk mengetahui makna Denotasi gambar peringatan kesehatan dalam Permenkes No 28 Tahun 2013 di kemasan rokok.

2. Untuk mengetahui makna Konotasi gambar peringatan kesehatan dalam Permenkes No 28 Tahun 2013 di kemasan rokok.

3. Untuk mengetahui makna Mitos gambar peringatan kesehatan dalam Permenkes No 28 Tahun 2013 di kemasan rokok.

\section{METODE PENELITIAN}

Metode yang digunakan dalam penelitian ini adalah metode analisis semiotika Roland Barthes, yang mana penelitian ini fokus pada objek kajiannya yaitu tanda-tanda. Karena metode analisisnya yang sangat bergantung pada interpretasi terhadap makna tanda-tanda, maka metode analisis semiotika bersifat kualitatif-interpretif. Patton memasukkan semiotika sebagai salah satu perspektif penelitian yang mengelaborasi bagaimana berbagai tanda (kata-kata atau simbolsimbol) mengarah pada makna-makna dalam konteks tertentu. (Michael Quinn Patton, Metode Evaluasi Kualitatif, Yogyakarta: Pustaka Pelajar, 2007, hal. 133). Metode analisis semiotik yang digunakan adalah pemikiran Roland 
Barthes. Alasan peneliti menggunakan analisis dengan pendekatan Roland Barthes yaitu karena pada pemikiran ini, makna dipahami dengan melalui dua tahap yaitu denotatif dan konotatif yang melingkupi mitos. Sehingga makna yang dihasilkan pun semakin kompleks dan mendalam.

\section{Sumber Data}

Sumber data adalah asal informasi tentang fokus penelitian itu didapat. Dalam hal ini sumber datanya adalah dokumen gambar peringatan kesehatan dalam Permenkes No. 28 Tahun 2013 pada media kemasan rokok. Sedangkan jenis data dalam penelitian ini di bagi menjadi dua yaitu data primer dan data sekunder. Data primer merupakan jenis data yang di peroleh langsung dari sumber asli (tidak melalui media perantara) yaitu berupa datakualitatif yang berasal dari data verbal dan data visual yang terdapat pada gambar peringatan kesehatan dalam Permenkes No. 28 Tahun 2013. Sedangkan data sekunder merupakan sumber data penelitian yang di peroleh peneliti secara tidak langsung melalui media perantara yaitu di peroleh dari buku-buku, makalah, jurnal dan berbagai sumber dari internet yang berkaitan dengan penelitian ini.

\section{Teknik Pengumpulan Data}

Teknik pengumpulan data merupakan cara yang digunakan peneliti untuk mendapatkan data dalam suatu penelitian. Adapun teknik pengumpulan data yang di gunakan penulis adalah sebagai berikut:

\section{Observasi}

Dalam teknik observasi penulis mengamati data-data yang sudah di transkipsi, diamati dan di pilih berdasarkan pemilihan tertentu. Kriteria pengamatan mengamati data yang mencakup persamaan dan perbedaan adanya penanda dan petanda, konotasi dan denotasi serta adanya mitos yang terbangun pada gambar peringatan kesehatan dalam Permenkes No 28 Tahun 2013.
2. Dokumentasi

Dokumentasi merupakan metode yang digunakan untuk mencari data mengenai hal-hal atau variabelvariabel yang berupa catatan, transkrip, buku, surat kabar, majalah dan lain sebagainya. Agar hasil penelitian ini akan semakin sah dan dapat dipercaya apabila didukung oleh foto-foto yang di dokumentasikan.

\section{Teknik Analisis Data}

Analisis data merupakan proses penyederhanaan data kedalam bentuk yang lebih mudah dan di interpretasikan. (Marsi Singarimbun, Metode Penelitian Survay, Jakarta: LP3LS, 1989, hal. 263). Dengan analisis ini data dapat di beri arti dan makna yang berguna dalam memecahkan masalah penelitian. oleh karna itu penelitian ini menggunakan semiologi yang pada dasarnya membolehkan pelibatan subyektifitas peneliti. Dalam analisis ini, peneliti menggunakan analisis model Roland Barthes yang menggunakan signifikasi dua tahap dalam melakukan penganalisisan terhadap obyek dengan harapan peneliti dapat menemukan makna dalam gambar peringatan kesehatan dalam Permenkes No 28 Tahun 2013.

Roland Barthes dalam menganalisis makna dari tanda-tanda menggunakan tahapan sebagai brikut: signifikasi tahap pertama merupakan hubungan antara signifier dan signified di dalam sebuah tanda terhadap realitas eksternal, Roland Barthes menyebutkan sebagai denotasi, yaitu makna paling nyata dari tanda. untuk menunjukkan tahap signifikasi kedua Roland Barthes menggunakan istilah konotasi, tahap ini menggunakan intraksi yang terjadi ketika tanda bertemu dengan perasaan atau emosi dari pembaca serta nilai-nilai dari kebudayaan yang ada.(Alex Sobur, Analisis Teks Media: Suatu Pengantar untuk Analisis Wacana, Analisis Semiotik dan Analisis Framming, Bandung: PT. Remaja Rosdakarya, 2004, hal. 128). 
Dari devinisi lain, penanda (signifier) adalah citraan atau kesan mental dari sesuatu yang bersifat verbal atau visual seperti suara, tulisan atau benda.Sedangkan petanda (signified) adalah konsep abstrak atau makna yang- di hasilkan oleh tanda. (Yasraf Amir Piliang, Sebuah Dunia yang Dilipat: Realitas Kebudayaan Menjelang Millenium Ketiga dan Matinya Posmodernisme, Bandung: Mizan, 1998, hal. 19). Piliang mengemukaan makna denotasi adalah hubungan eksplisit antara tanda dengan referensi atau realitas dalam pertandaan. sedangkan makna konotasi adalah aspek pemaknaan yang berkaitan dengan perasaan dan emosi serta nilai-nilai kebudayaan dan ideology. (Sumbo Tinarbuko, Semiotika Komunikasi Visual, Yogyakarta: Jalasutra, 2009, hal. 20).

Simiologi Roland Barthes (pengikut Sausssure) membuat model sistematis dalam menganalisa makna dari tanda-tanda. fokus penelitianya tertuju pada gagasan tentang signifikasi dua tahap (two order of signification). signifikasi tahap pertama merupakan hubungan antara signifier (penanda) dan signified (petanda) didalam sebuah tanda terhadap realitas eksternal. Roland Barthes menyebutnya sebagai denotasi, yaitu makna paling nyata dari sebuah tanda. Konotasi adalah sebuah istilah Roland Barthes untuk menyebut signifikasi tahap ke dua yang menggambarkan interaksi yang terjadi

\section{HASIL PENELITIAN DAN PEMBAHASAN}

Dari hasil penelitian ini, ditemukan adanya makna yang mencakupi signifier (penanda) dan signified (petanda), Denotasi, Konotasi dan Mitos. Berdasarkan signifikasi dua tahap dari Roland Barthes yang dibedakan atas penanda petanda, maka selanjutnya peneliti akan mengupas dan menganalisis penelitian ini berdasarkan tanda tersebut, mulai dari makna eksplisit, yaitu makna berdasarkan apa yang tampak (Denotatif), serta makna mendalam yang berkaitan dengan pemahaman ideologi dan kultural ketika tanda bertemu dengan perasaan atau emosi dari pembaca serta nilai-nilai kebudayaan. Konotasi mempunyaii nilai yang subyektif atau intersubyektif. Denotasi adalah apa yang di gambarkan tanda terhadap subyek, sedangkan konotasi adalah bagaimana menggambarkanya.

Dalam pelaksanaan analisis data, peneliti terlebih dahulu membuat analisis simiotik yang berisikan elemen-elemen dari gambar peringatan kesehatan yang di klasifikasikan kedalam elemen verbal dan elemen visual setelah itu baru di bedakan penanda-petandanya dan makna denotasi dan- konotasinya. Kemudian setelah membuat analisis semiotika maka peneliti membuat analisis deskritipnya dari makna denotasi dan konotasi. Data yang telah di pilih kemudian di analisa dengan landasan teori yang telah di tentukan sebelumnya. Langkah-langkah yang di ambil dalam menganalisa data adalah sebagai berikut:

1. Menganalisa hubungan antara penanda (signifier) dengan petanda (signified) antara bentuk atau ekspresi gambar peringatan kesehatan pada kemasan rokok dalam peraturan Permenkes No 28 Tahun 2013 dengan makna yang terkandung di dalanya.

2. Menganalisa makna denotasi dan konotasi serta mitos dari gambar peringatan kesehatan dalam Permenkes No 28 Tahun 2013.

(Konotatif) dan makna hubungan konotasi dan denotasi secara mendalam (Mitos). Berikut paparan mengenai analisis semiotika tentang tanda yang terdapat dalam permenkes No 28 Tahun 2013:

\section{Gambar Merokok Sebabkan Kangker Mulut}

a. Analisis Makna Denotatif Pada Gambar Merokok sebabkan Kangker Mulut.

1. Label Judul Bertuliskan Peringatan

Label berbentuk kolom persegi panjang dengan latar belakang 
berwarna hitam pekat tanpa gradasi atau aksen-aksen tertentu dan pada label ini berisi teks 'PERINGATAN', teks ini di tulis dengan tulisan berbahasa Indonesia, berukuran 10 font dan teks tersebut seluruhnya menggunakan huruf kapital. Teks ini menggunakan paragraph tengah sedangkan Jenis huruf atau font yang digunakan dalam teks ini adalah Arial Bold dengan warna putih terang. Terlihat jelas disini bahwa tulisan berwarna putih dipadukan dengan latar berwarna hitam.

2. Kolom Label Dengan Tulisan Merokok Sebabkan Kangker Mulut

Label berbentuk kolom berlatar belakang berwarna hitam pekat berisi teks dengan tulisan 'MEROKOK SEBABKAN KANGKER MULUT'. Teks ini menggunakan tulisan bahasa Indonesia berukuran 4 font dan keseluruhan teks tersebut berhuruf kapital. teks menggunakan paragraf tengah sedangkan jenis huruf yang digunakan dalam label ini adalah Arial berwarna putih polos tanpa tekstur warnawarna lain.

3. Gambar Bibir Yang Penuh Dengan Luka Kudis Yang Menjijikkan

Ini adalah gambar bibir yang terkena penyakit kangker mulut. Mulut tampak sedikit menganga, bagian bibir bawah di penuhi dengan luka kudis yang menjijikan, pada luka tersebut terdapat lendir-lendir berupa nanah dan bercakbercak hitam yang hamper menutupi batas area bibir, area sekitar mulut telah mengkriput hal ini tampak dari garis-garis yang terdapat pada kulit area sekitar mulut yang disebabkan luka tersebut, pada bibir juga terdapat benjolan-benjolan yang tak beraturan yang menandakan luka sudah parah, pada kulit sekitar area mulut telah berwarna keunguan yang menandakan luka-luka tersebut telah menyebar ke area lain.

b. Analisis Makna Konotatif Pada Gambar Merokok Sebabkan Kangker Mulut.

1. Label Judul Bertuliskan Peringatan

Label berwarna hitam pekat secara umum menunjukan makna kekuatan, sesuatu yang misterius, namun dalam hal ini juga bisa bermakna kegelapan, sesuatu yang kelam, kematian, energi negatif, atau bahkan sesuatu yang horor atau menakutkan. Jenis huruf Arial Bold yang digunakan melambangkan kesederhanaan, sikap lugas, modern, dan futuristik. Penggunaan warna putih pada font ini menunjukan seolah tulisan ini 'ingin mencuri perhatian' ketika dipadukan dengan warna latar hitam. Dalam unsur visual ini, prinsip kontras (gelap-terang) digunakan dalam desain ini. Tujuannya adalah untuk menonjolkan informasi dan membantu meningkatkan nilai keterbacaannya. Penggunaan warna hitam dalam label ini bisa jadi penunjang kesatuan dari seluruh unsur visual dalam peringatan ini, karena warna hitam juga identik dengan maskulinitas atau kelelakian, dimana umumnya konsumen rokok adalah kaum pria. Dengan menggunakan unsur 
ini, tentu saja aspek kedekatan makna secara psikologis juga bisa digunakan untuk menyampaikan pesan. Dari sisi jenis huruf atau font, yang digunakan adalah Arial. Jenis huruf ini termasuk dalam kategori huruf Sans Serif atau huruf dengan desain tanpa kait diujungnya. Menurut peneliti, penggunaan jenis huruf ini sangat tepat karena bila menggunakan font yang terlalu artistik dikhawatirkan tulisan isi pesan malah lebih sulit terbaca ata kurang menarik perhatian.

2. Kolom Label Dengan Tulisan Merokok Sebabkan Kangker Mulut

Tanda verbal berupa label denagn latar belakang berwarna hitam pekat pada tulisan MEROKOK SEBABKAN KANGKER MULUT' selain berfungsi menonjolkan kata-kata tersebut yang dicetak dengan warna putih juga dapat dimaknai berdasarkan respon psikologis yang ditimbulkannya di mana berarti kekuatan, kematian, misteri, dan ketidakbahagiaan. Hal ini berarti informasi kesehatan disampaikan secara kuat, mengandung ketidakbahagiaan, dan mengancam di mana kangker mulut adalah akibat bila mengabaikan hal yang diinformasikan.

3. Gambar Bibir Yang Penuh Dengan Luka Yang Menjijikkan

Pada gambar ini tapak ekpresi mulut yang ternganga seolah sulit untuk menutup kembali hal ini dikarnakan luka dan pembengkaan yang ada di bagian bibir bawah, dari ekspresi yang tegang, ketegangan ini jika di kaitkan dengan unsur psikologis menandakan perasaan yang tak biasa dalam hal ini bisa sajakarna rasa sakit yang tertahan, Tampak warrna kuning kemerahan pucat dan bercak-bercak hitam yang di balut oleh lender-lendir pada luka warna-warna tersebut memberi kesan yang menjijikkan dan ini menandakan luka yang sudah membusuk dan dapat di golongkan pada golongan luka yang sangat serius yang berdampak bahaya karna dapat menyebar ke organ tubuh lain, gambar ini hanya diambil pada fokus bagian area mulut saja dikarnakan pesan yang ingin di sampaikan adalah dampak keseriusan penyakit yang disebabkan akibat mengkonsumsi rokok sehingga menyebabkan penyakit kangker mulut.

c. Analisis Makna Mitos Pada Gambar Merokok sebabkan Kangker Mulut.

Gambar berupa ilustrasi mulut manusia yang mengalami kerusakan menjadi acuan akan kata "Kanker Mulut" dan ini yang menjadi tanda yang memberikan gambaran mental pada pembaca sesuai dengan pengalaman sebelumnya. Tanda visual berupa ilustrasi mulut manusia yang mengalami kerusakan yang terpampang di bagian pusat peringatan kesehatan ini merupakan teknik agar menjadi pusat perhatian dari pembaca, jadi untuk menonjolkan "Kanker Mulut” yang diperingatkan. Adanya pemasangan ilustrasi mulut manusia yang mengalami kerusakan dalam gambar peringatan kesehatan tentu memberikan informasi, edukasi, dan batasan tentang bagaimana kanker 
mulut yang dimaksud oleh pengirim pesan, yaitu kanker yang menggerogoti daerah mulut sehingga bagian bibir mengalami kerusakan paling parah., mungkin akan didapat pengertian misalnya, kanker mulut adalah penyakit berbahaya yang bila tidak segera diobati penyakitnya akan terus berkembang dan menggerogoti bagian tubuh yang lain. Kemudian ini akan mengalami proses lebih lanjut yang mungkin akan menjadi, bila keadaannya sudah sangat parah maka akan mengancam nyawa karena itu perlu penanganan medis dengan biaya yang mahal karena penyakit kanker tidak sama seperti penyakit-penyakit lain yang dapat segera sembuh dengan berobat sekali jalan. Tidak hanya itu penderita akan merasa malu karena terjadi perubahan bentuk fisik yang menonjol di wajahnya, kalau sudah begitu ia akan menutup diri dan enggan berbaur kepada lingkunganya karna ia beranggapan bahwa lingkungan akan menolaknya. Foto kangker mulut ini disebabkan akibat seseorang yang mengabaikan peringatan karena kurangnya kepedulian terhadap kesehatan dan foto yang tercantum pada kemasan rokok ini merupakan ancaman keras kepada perokok apabila tidak berhenti merokok maka akan terserang kangker mulut seperti pada gambar tersebut.

2. Gambar Merokok Membunuhmu

a. Analisis Makna Denotatif Pada Gambar Merokok sebabkan Kangker Mulut

1. Label Judul Bertuliskan Peringatan

Label berbentuk kolom persegi panjang dengan latar belakang berwarna hitam pekat tanpa gradasi atau aksen-aksen tertentu dan pada label ini berisi teks 'PERINGATAN', teks ini di tulis dengan tulisan berbahasa Indonesia, berukuran 10 font dan teks tersebut seluruhnya menggunakan huruf kapital. Teks ini menggunakan paragraph tengah sedangkan Jenis huruf atau font yang digunakan dalam teks ini adalah Arial Bold dengan warna putih terang. Terlihat jelas disini bahwa tulisan berwarna putih dipadukan dengan latar berwarna hitam.

2. Kolom Label Dengan Tulisan Membunuhmu

Label berbentuk kolom berlatar belakang berwarna hitam pekat berisi teks dengan tulisan 'MEROKOK MEMBUNUHMU'. Teks ini menggunakan tulisan bahasa Indonesia berukuran 4 font dan keseluruhan teks tersebut berhuruf kapital. teks menggunakan paragraf tengah sedangkan jenis huruf yang digunakan dalam label ini adalah Arial berwarna putih polos tanpa tekstur warnawarna lain.

3. Gambar Pria Yang Sedang Merokok

Unsur visual pada Gambar seorang pria yang sedang menghembuskan asap rokok yang dijepit diantara dua jarinya. Pria berkumis dan berkulit wajah agak gelap ini tampak seperti pria ras melayu pada umumnya (seperti kebanyakan orang Indonesia). Rambutnya pendek berwarna hitam dan sedikit terpapar refleksi dari sinar lampu. Ekspresinya tampak serius, menghadap ke arah kanan. Terlihat kontras sekali dengan latar belakang gambar yang berwarna hitam. Dalam 
gambar ini tidak begitu jelas pakaian yang dikenakannya, bahkan terlihat seperti bertelanjang dada dengan posisi menyamping. Sementara itu asap putih tebal tampak keluar dari mulutnya yang sedikit terbuka.

4. Ilustrasi Gambar Dua

Tengkorak

Dua buah tengkorak tampak berada di bagian belakang pria perokok. Posisi keduanya bersebelahan namun tidak sejajar, satu tengkorak berada agak diatas, sementara satunya lagi berada agak kebawah. Dari segi ukuran, tengkorak tersebut sepertinya berukuran tengkorak orang dewasa. Namun tengkorak di bagian bawahnya lebih besar dibanding yang satunya lagi dan juga lebih rusak gigi dan batok kepalanya yang terlihat berlubang. Ilustrasi tengkorak ini agak buram karena posisinya di belakang dan sedikit terhalang asap putih di depannya.

b. Analisis Makna Konotatif Pada Gambar Merokok Membunuhmu

1. Label Judul Bertuliskan Peringatan

Label berwarna hitam pekat secara umum menunjukan makna kekuatan, sesuatu yang misterius, namun dalam hal ini juga bisa bermakna kegelapan, sesuatu yang kelam, kematian, energi negatif, atau bahkan sesuatu yang horor atau menakutkan. Jenis huruf Arial Bold yang digunakan melambangkan kesederhanaan, sikap lugas, modern, dan futuristik. Penggunaan warna putih pada font ini menunjukan seolah tulisan ini 'ingin mencuri perhatian' ketika dipadukan dengan warna latar hitam. Dalam unsur visual ini, prinsip kontras (gelap-terang) digunakan dalam desain ini. Tujuannya adalah untuk menonjolkan informasi dan membantu meningkatkan nilai keterbacaannya. Penggunaan warna hitam dalam label ini bisa jadi penunjang kesatuan dari seluruh unsur visual dalam peringatan ini, karena warna hitam juga identik dengan maskulinitas atau kelelakian, dimana umumnya konsumen rokok adalah kaum pria. Dengan menggunakan unsur ini, tentu saja aspek kedekatan makna secara psikologis juga bisa digunakan untuk menyampaikan pesan. Dari sisi jenis huruf atau font, yang digunakan adalah Arial. Jenis huruf ini termasuk dalam kategori huruf Sans Serif atau huruf dengan desain tanpa kait diujungnya. Menurut peneliti, penggunaan jenis huruf ini sangat tepat karena bila menggunakan font yang terlalu artistik dikhawatirkan tulisan isi pesan malah lebih sulit terbaca ata kurang menarik perhatian.

2. Kolom Label Dengan Tulisan Merokok Membunuhmu

Tanda verbal berupa label denagn latar belakang berwarna hitam pekat pada tulisan "Merokok Membunuhmu" selain berfungsi menonjolkan kata-kata tersebut yang dicetak dengan warna putih juga dapat dimaknai berdasarkan respon psikologis yang ditimbulkannya di mana berarti kekuatan, kematian, misteri, dan ketidakbahagiaan. Hal ini berarti informasi kesehatan ini disampaikan secara kuat, 
mengandung ketidak

bahagiaan, dan mengancam di mana kematian adalah akibat bila mengabaikan hal yang diinformasikan.

3. Gambar Pria Yang Sedang Merokok

Pria dalam gambar ini Menunjukan makna proximity atau kedekatan emosional secara ras kepada sasaran audiens pesan peringatan ini yaitu orang Indonesia secara umum. Dari sisi ekspresinya, wajah pria dalam gambar ini nampak serius (sedikit mengernyitkan dahi dan memicingkan mata). Pria ini seperti sedang memikirkan sesuatu hal, persis seperti yang dilakukan oleh sebagian perokok ketika sedang membutuhkan inspirasi atau bahkan sedang galau hatinya. Dalam kehidupan seharihari terkadang kita menemukan seorang perokok yang menggunakan alasan merokok sebagai sebuah kegiatan untuk mendukung inspirasinya dalam sebuah kegiatan atau karya. Artinya jika tidak merokok, mereka merasa sulit berpikir atau mengerjakan sesuatu atau menenangkan hatinya yang sedang dirundung suatu masalah. Padahal secara kesehatan tentu saja rokok malah menambahkan masalah kesehatan secara fisik kepada pecandunya. Dalam foto ini pria tersebut seolah mewakili kebiasaan perokok tersebut. Posenya yang sedang menjepit rokok diantara jarinya dengan asap putih tebal yang nampak keluar dari mulutnya menunjukan makna betapa aktivitas merokok begitu nyaman dilakukannya.
Merokok baginya seolah merupakan kegiatan yang begitu nikmat dilakukan, begitu menginspirasi.

4. Ilustrasi Gambar Dua Tengkorak

Tengkorak dalam ilustrasi ini mengandung makna kematian, apalagi dengan posisinya yang berada di belakang si perokok seolah kematian itu mengintai si perokok. Secara harfiah tengkorak adalah bagian tubuh manusia yang tetap awet dan tidak membusuk meskipun seseorang sudah meninggal dunia. Sehingga bila muncul gambaran sosok tengkorak yang terekspos secara eksplisit seperti ini, konotasi yang langsung terbayangkan adalah kematian. Dalam ilustrasi tengkorak ini, penampilannya saja sudah sangat mengerikan, apalagi terdapat salah satu tengkorak yang tampak rusak (terdapat lubang di batok kepala dan susunan giginya). Kesan menakutkan, horor, dan sejumlah makna negatif yang ditimbulkan semakin kuat dengan adanya tengkorak ini. Apalagi dengan latar warna hitam dan gelap dalam ilustrasi ini yang tampak lebih menakutkan.

c. Analisis Makna Mitos Pada Gambar Merokok Membunuhmu.

Makna mitos merokok membunuhmu dalam gambar ini tampak pria yang sedang merokok dengan asap yang mengepul dan di sampingnya terdapat dua buah tengkorak, kebiasaan merokok merupakan suatu hal yang sudah membudaya dalam kehidupan masyarakat, wajar, dan bukan sesuatu hal yang mengerikan. 
Merokok meski berbahaya bagi kesehatan diri dan orang sekitar, pada visualisasi ini dipersepsikan sebagai potret keseharian masyarakat kita yang sudah biasa merokok dimanapun dan kapanpun, bahkan di dekat kelompok masyarakat berusia rentan sekalipun seperti anak-anak atau orang sakit. Makna mitos rokok sebagai suatu sarana 'inspirasi semu' berkarya oleh kelompok orang yang akrab dengan identitas bersimbol tengkorak, yang dalam tujuan pesan disini untuk 'menakuti' justru bisa menjadi inspirasi berkarya bagi kelompok yang menggunakan simbol tengkorak sebagai identitas misalnya musisi beraliran musik rock atau metal. Meskipun sebetulnya itu hanyalah bersifat semu atau palsu, hanya berupa stimulus bagi pikiran bawah mitos yang ditawarkan dari gambar peringatan "merokok membunuhmu" adalah bahwa seseorang yang merokok akan dibunuh oleh rokok yang dihisapnya. Gambar pria disini mewakili tingginya angka perokok pria yang ada di Indonesia seperti kita tau bawasanya di setiap tahunnya perokok di Indonesia semakin bertambah jumlahnya. Penggunaan gambar tengkorak merupakan perwakilan dari kematian yang mana tengkorak ini lebih identik dengan orang yang sudah meninggal yang menyisahkan tulang belulang yang pastinya lebih menyeramkan. Ketika sasaran memaknai gambar peringatan ini, maka terlihat kecendrungan sasaran pada kategori usia tua memiliki makna yang berada di posisi makna dominan, jika dibandingkan kategori usia muda. Gambar ini merupakan bentuk ancaman yang serius bagi perokok untuk berhenti merokok atau tetap merokok sehingga akan mati sia-sia karena rokok dan seperti tengkorak yang berada persis di belakang si perokok pada gambar tersebut.

\section{Gambar Merokok Sebabkan Kanker Tenggorokan}

a. Analisis Makna Denotatif Pada Gambar Merokok sebabkan Kangker Tenggorokan

1. Label Judul Bertuliskan Peringatan

Label berbentuk kolom persegi panjang dengan latar belakang berwarna hitam pekat tanpa gradasi atau aksen-aksen tertentu dan pada label ini berisi teks 'PERINGATAN', teks ini di tulis dengan tulisan berbahasa Indonesia, berukuran 10 font dan teks tersebut seluruhnya menggunakan huruf kapital. Teks ini menggunakan paragraph tengah sedangkan Jenis huruf atau font yang digunakan dalam teks ini adalah Arial Bold dengan warna putih terang. Terlihat jelas disini bahwa tulisan berwarna putih dipadukan dengan latar berwarna hitam.

2. Kolom Label Dengan Tulisan Merokok Sebabkan Kangker Tenggorokan

Label berbentuk kolom berlatar belakang berwarna hitam pekat berisi teks dengan tulisan 'MEROKOK SEBABKAN KANGKER TENGGOROKAN'. Teks ini 
menggunakan tulisan bahasa Indonesia berukuran 4 font dan keseluruhan teks tersebut berhuruf kapital. teks menggunakan paragraf tengah sedangkan jenis huruf yang digunakan dalam label ini adalah Arial berwarna putih polos tanpa tekstur warnawarna lain.

3. Gambar Tenggorokan Yang Berlubang Disertai Luka Kudis Di Sekitarnya

gambar ini adalah gambar pria dewasa yang menderita penyakit kangker tenggorakan pada gambar ini tampak pria yang tidak menggenakan baju yang sedang menunjukkan penyakit yang ia derita di bagian lehernya, adapun luka pada bagian leher yaitu tenggorokan yang berlobang yang menyeramkan dan di pangkal dagu terdapat benjolan berwarna merah pucat berlendir putih, pada area sekitar leher kulit mengkriput dan berwarna merah kehitaman, pada bagian pangkal leher terlihat otot-otot yang berkontraksi tegang seperti menahan rasa sakit. Pada bagian latar belakang foto tampak seperti tirai berwarna biru. Tirai ini semacam pembatas yang sering di jumpai di rumah sakit atau di tempat medis lainya.

b. Analisis Makna Konotatif Pada Gambar Merokok sebabkan Kangker Tenggorokan

1. Label Judul Bertuliskan Peringatan

Label berwarna hitam pekat secara umum menunjukan makna kekuatan, sesuatu yang misterius, namun dalam hal ini juga bisa bermakna kegelapan, sesuatu yang kelam, kematian, energi negatif, atau bahkan sesuatu yang horor atau menakutkan. Jenis huruf Arial Bold yang digunakan melambangkan kesederhanaan, sikap lugas, modern, dan futuristik. Penggunaan warna putih pada font ini menunjukan seolah tulisan ini 'ingin mencuri perhatian' ketika dipadukan dengan warna latar hitam. Dalam unsur visual ini, prinsip kontras (gelap-terang) digunakan dalam desain ini. Tujuannya adalah untuk menonjolkan informasi dan membantu meningkatkan nilai keterbacaannya. Penggunaan warna hitam dalam label ini bisa jadi penunjang kesatuan dari seluruh unsur visual dalam peringatan ini, karena warna hitam juga identik dengan maskulinitas atau kelelakian, dimana umumnya konsumen rokok adalah kaum pria. Dengan menggunakan unsur ini, tentu saja aspek kedekatan makna secara psikologis juga bisa digunakan untuk menyampaikan pesan. Dari sisi jenis huruf atau font, yang digunakan adalah Arial. Jenis huruf ini termasuk dalam kategori huruf Sans Serif atau huruf dengan desain tanpa kait diujungnya. Menurut peneliti, penggunaan jenis huruf ini sangat tepat karena bila menggunakan font yang terlalu artistik dikhawatirkan tulisan isi pesan malah lebih sulit terbaca ata kurang menarik perhatian.

2. Kolom Label Dengan Tulisan Merokok Sebabkan Kangker Tenggorokan

Tanda verbal berupa label denagn latar belakang berwarna hitam pekat pada 
tulisan

'MEROKOK

SEBABKAN KANGKER

TENGGOROKAN' selain

berfungsi menonjolkan katakata tersebut yang dicetak dengan warna putih juga dapat dimaknai berdasarkan respon psikologis yang ditimbulkannya di mana berarti kekuatan, kematian, misteri, dan ketidakbahagiaan. Hal ini dapat berarti informasi kesehatan ini disampaikan secara kuat, mengandung ketidakbahagiaan, dan mengancam di mana kangker tenggorokan adalah akibat bila mengabaikan hal yang diinformasikan.

3. Gambar Tenggorokan Yang Berlubang Disertai Luka Kudis Di Sekitarnya (Kangker Tenggorokan)

Gambar pengingat dari merokok, akibat merokok, kanker tenggorokan, tampilan gejala yang ditimbulkan karena kanker tenggorokan adalah lubang menganga dan benjolan berwarna merah. Penanda dan petanda ini membawa kita pada pemahaman langsung bahwa peringatan kesehatan ini tentang gejala dari suatu jenis penyakit berbahaya, yaitu kanker tenggorokan yang menjangkiti seseorang karena mengkonsumsi rokok yang mengantarkannya ke Rumah Sakit. Konotasi yang muncul, dengan mengkonsumsi rokok berarti tubuh akan menanggung resiko mengalami kecacatan fisik seperti yang dinasehatkan, aktivitas merokok merupakan jalan bagi penyakit kanker tenggorokan menyerang tubuh manusia. Pemaknaan ini ditunjang dengan warna biru pada semacam tirai di belakang pria tersebut dengan kanker tenggorokan yang siap ditandai sebagai pembatas ruangan yang biasa ditemui di Rumah Sakit. Apalagi jika mengingat warna-warna yang biasa diaplikasikan untuk Rumah Sakit atau tempat-tempat medis lainnya adalah putih, hijau ,dan- biru. Dan tak jarang dekorasi di dalamnya pun turut disesuaikan warnanya agar selaras. Maka tak berlebihan mengatakan ilustrasi fotografi ini diambil ketika sang objek berada di ruang Rumah Sakit. Kemudian karena pencantuman gambar peringatan kesehatan ini dimaksudkan untuk memberi efek kejut, agaknya kehadiran warna biru memberikan dampak lain. Sebab dibalik pemilihan warna ini ada hubungannya dengan efek psikologis. Desainer, psikolog, dan ahli Feng-Shui, mereka semua cenderung untuk mempertimbangkan bahwa nuansa biru dan hijau pada dinding rumah sakit membuat kita jauh lebih tenang, lebih seimbang, lebih sedikit emosional. Senada dengan hal tersebut, Molly E. Holzhlag yang pemikirannya tentang warna dijadikan patokan dalam penelitian ini juga menyebut warna biru dapat memberikan respon psikologis konservatif dan keamanan.

c. Analisis Makna Mitos Pada Gambar Merokok Sebabkan Kangker Tenggorokan.

Kangker tenggorokan adalah tumor ganas yang tumbuh di area tenggorokan, sebagian besar kangker ini di mulai pada bagian laring dimana pita suara berasal, laring ini 
berperan penting untuk bernafas, menelan dan berbicara. Dari hasil penelitian resiko kangker tenggorokan bisa meningkat dengan lamanya waktu seorang merokok dan akan menjadi lebih parah apabila perokok mengkonsumsi alcohol. Merokok merupakan salah satu kegiatan penyebab utama kangker tenggorokan karna di dalam tembakau mengandung banyak zat karsinogen dan zat ini lah yang mengakibatkan kangker tenggorakan. Mitos yang terkandung adalah kesedihan seorang penderita kangker tenggorokan yang tergambar pada ruang medis, kesedihan yang di tunjukkan ini akibat mengabaikan peringatan merokok sebabkan kangker tenggorokan dan gambar ini merupakan bentuk ancaman ang ditujukan pada perokok untuk memilih berhenti merokok atau terserang kangker tenggorokan.

\section{Gambar Orang Merokok Dekat} Anak Berbahaya Bagi Mereka

a. Analisis Makna Denotatif Pada Gambar Dekat Anak Berbahaya Bagi Mereka
1. Label Judul Bertuliskan Peringatan
Label berbentuk kolom persegi panjang dengan latar belakang berwarna hitam pekat tanpa gradasi atau aksen-aksen tertentu dan pada label ini berisi teks 'PERINGATAN', teks ini di tulis dengan tulisan berbahasa Indonesia, berukuran 10 font dan teks tersebut seluruhnya menggunakan huruf kapital. Teks ini menggunakan paragraph tengah sedangkan Jenis huruf atau font yang digunakan dalam teks ini adalah Arial Bold dengan

warna putih terang. Terlihat jelas disini bahwa tulisan berwarna putih dipadukan dengan latar berwarna hitam.

2. Kolom Label Dengan Tulisan Merokok Dekat Anak Berbahaya Bagi Mereka

Label berbentuk kolom berlatar belakang berwarna hitam pekat berisi teks dengan tulisan 'MEROKOK DEKAT ANAK BERBAHAYA BAGI MEREKA'. Teks ini menggunakan tulisan bahasa Indonesia berukuran 4 font dan keseluruhan teks tersebut berhuruf kapital. teks menggunakan paragraf tengah sedangkan jenis huruf yang digunakan dalam label ini adalah Arial berwarna putih polos tanpa tekstur warnawarna lain.

3. Gambar Pria Yang Merokok Sambil Menggendong Seorang Anak Kecil.

Pada gambar ini tampak seorang pria berambut ikal dan lebat dengan rambut berwarna hitam sedikit kekuningkuningan dan memiliki kulit berwarna coklat sawo matang, Tangan pria ini tampak sedang menjepit sebatang rokok dengan menggunakan jari tengah dan jari telunjuknya dan posisi tangan menghadap ke arah mulut. Peria ini menggenakan baju berwarna biru berpose menghadap kedepan, sambil menghembuskan kepulan asap ke udara, peria ini sedang mengendong anak kecil yang menggenakan baju berwarna putih bercorak dan menghadap ke samping kanan mengarah pada sebatang rokok. Tampak pada gambar tersebut bahwa tangan kanan sianak tersebut 
ingin mengapai tangan peria yang sedang menjepit sebatang rokok.

b. Analisis Makna Konotatif Pada Gambar Dekat Anak Berbahaya Bagi Mereka

1. Label Judul Bertuliskan Peringatan

Label berwarna hitam pekat secara umum menunjukan makna kekuatan, sesuatu yang misterius, namun dalam hal ini juga bisa bermakna kegelapan, sesuatu yang kelam, kematian, energi negatif, atau bahkan sesuatu yang horor atau menakutkan. Jenis huruf Arial Bold yang digunakan melambangkan kesederhanaan, sikap lugas, modern, dan futuristik. Penggunaan warna putih pada font ini menunjukan seolah tulisan ini 'ingin mencuri perhatian' ketika dipadukan dengan warna latar hitam. Dalam unsur visual ini, prinsip kontras (gelap-terang) digunakan dalam desain ini. Tujuannya adalah untuk menonjolkan informasi dan membantu meningkatkan nilai keterbacaannya. Penggunaan warna hitam dalam label ini bisa jadi penunjang kesatuan dari seluruh unsur visual dalam peringatan ini, karena warna hitam juga identik dengan maskulinitas atau kelelakian, dimana umumnya konsumen rokok adalah kaum pria. Dengan menggunakan unsur ini, tentu saja aspek kedekatan makna secara psikologis juga bisa digunakan untuk menyampaikan pesan. Dari sisi jenis huruf atau font, yang digunakan adalah Arial. Jenis huruf ini termasuk dalam kategori huruf Sans Serif atau huruf dengan desain tanpa kait diujungnya. Menurut peneliti, penggunaan jenis huruf ini sangat tepat karena bila menggunakan font yang terlalu artistik dikhawatirkan tulisan isi pesan malah lebih sulit terbaca ata kurang menarik perhatian.

2. Kolom Label Dengan Tulisan Merokok Dekat Anak Berbahaya Bagi Mereka

Tanda verbal berupa label denagn latar belakang berwarna hitam pekat pada tulisan "MEROKOK DEKAT ANAK BERBAHAYA BAGI MEREKA" selain berfungsi menonjolkan kata-kata tersebut yang dicetak dengan warna putih juga dapat dimaknai berdasarkan respon psikologis yang ditimbulkannya di mana berarti kekuatan, kematian, misteri, dan ketidakbahagiaan. Hal ini berarti informasi kesehatan ini disampaikan secara kuat, mengandung ketidakbahagiaan, dan mengancam di mana dampak terhadap anak adalah akibat bila mengabaikan peringatan yang diinformasikan.

3. Gambar Pria Yang Merokok Sambil Menggendong Seorang Anak Kecil

Menggendong memberikan kesan keintiman atau jarak personal yang menghubungkan relasi orangtua dan anak. Lebih lanjut, pemerintah- nampaknya jeli menangkap hal yang dapat digunakan untuk mendukung gambaran orang tua dan anak ini melalui pemilihan warna pakaian yang mereka kenakan. Warna biru seperti yang telah disinggung sebelumnya memberikan respon psikologis keamanan dan konservatif. 
Dalam konteks kekeluargaan warna biru dapat mempertegas identitas orangtua, di mana menjadi hal yang alami bagi mereka untuk senantiasa memberikan perlindungan dan rasa aman bagi anak-anaknya, baik dari ancaman dari luar maupun dari diri mereka sendiri. Kemudian warna putih pada pakaian si anak memberi respon psikologis kemurnian atau suci, bersih, innocent (tanpa dosa), dan steril. Karena itu hal ini menunjukan ciri-ciri seorang anak yang mana suci tanpa dosa. Kemudian melihat gestur si anak yang berusaha meraih tangan ayahnya yang sedang mengapit sebatang rokok, ditambah pemaknaan warna abu-abu pada latar belakang gambar yang berdasarkan respon psikologis menunjukan kesenduan dan merusak, agaknya baik si anak maupun orangtuanya tak mengetahui bahaya yang mengancamnya.

c. Analisis Makna Mitos Pada Gambar Merokok Dekat Anak Berbahaya Bagi Mereka

Gambar diatas adalah gambar peringatan kesehaata yang mengilustrasikan seorang pria sedang menggendong anak kecil sambil merokok, merokok sambil mengendong anak atau merokok di dekat anak sepertinya merupakan kebiasaan yang sudah membudaya di kalangan masyarakat. Hal seperti ini tentunya sering sekali kita jumpai di lingkungan sekitar kita. anak kecil memiliki organ tubuh yang rentang, semua organ-organ di dalam tubuhnya masih begitu lemah dan belum setabil apabila si anak terhirup oleh asap rokok maka asap tersebut akan cepat sekali bereaksi dan menyebabkan penyakit pada si anak tersebut, merokok didekat anak sangat berbahaya bagi mereka hal ini tidak hanya berpengaruh pada kesehatan si anak saja tetapi nantinya akan berdapak negatif bagi perkembangan dan pertumbuhan si anak tersebut baik dari fisik maupun mental. Gambar ini merupakan teguran keras sekaligus peringatan bagi orang tua anak atau perokok lainya bawasanya dampak Perokok pasif memiliki bahaya yang lebih tinggi di bandingkan dengan perokok aktif.

\section{Gambar Merokok Sebabkan Kanker Paru-Paru Dan Bronkitis Kronis}

a. Analisis Makna Denotatif Pada Gambar Merokok Sebabkan Kangker Paru-Paru Dan Bronkitis Kronis

1. Label Judul Bertuliskan Peringatan

Label berbentuk kolom persegi panjang dengan latar belakang berwarna hitam pekat tanpa gradasi atau aksen-aksen tertentu dan pada label ini berisi teks 'PERINGATAN', teks ini di tulis dengan tulisan berbahasa Indonesia, berukuran 10 font dan teks tersebut seluruhnya menggunakan huruf kapital. Teks ini menggunakan paragraph tengah sedangkan Jenis huruf atau font yang digunakan dalam teks ini adalah Arial Bold dengan warna putih terang. Terlihat jelas disini bahwa tulisan berwarna putih dipadukan dengan latar berwarna hitam.

2. Kolom Label Dengan Tulisan Merokok Sebabkan Kangker Paru-Paru Dan Bronkitis Kronis.

Label berbentuk kolom berlatar belakang berwarna hitam pekat berisi teks dengan 
tulisan

'MEROKOK

SEBABKAN KANGKER

PARU-PARU DAN

BRONKITIS KRONIS'. Teks

ini menggunakan tulisan

bahasa Indonesia berukuran 4

font dan keseluruhan teks

tersebut berhuruf kapital. teks

menggunakan paragraf tengah

sedangkan jenis huruf yang

digunakan dalam label ini

adalah Arial berwarna putih

polos tanpa tekstur warna-

warna lain.

3. Gambar Pria Sedang Terbaring

Dengan Bagian Dada Tampak

Paru-Paru Yang Menghitam

Karna Kangker Dan Bronkitis

Kronis.

Pada gambar ini tampak seorang pria yang terbaring lemah dengan sikap badan terlentang dengan kulit berwarna putih pucat tanpa mengenakan pakaian dan bagian dada terlihat jelas tanpak terbuka yang mana dada terbelah berbentuk setengah oval hingga tampak organ tubuhnya yaitu paruparu. Pada gambar tampak paru-paru yang berwarna keabu-abuan dan hampir semua bagian organ paru-paru yang tapak pada gambar tersebut tertutupi oleh warna hitam keabu-abuan yang di sebabkan oleh endapan asap yang menempel pada organ paru-paru tersebut dan di pinggir batas terlihat luka tampak bercak-bercak darah yang berada di sayatan daging.

b. Analisis Makna Konotatif Pada Gambar Merokok Sebabkan Kangker Paru-Paru Dan Bronkitis Kronis.

1. Label Judul Bertuliskan Peringatan
Label berwarna hitam pekat secara umum menunjukan makna kekuatan, sesuatu yang misterius, namun dalam hal ini juga bisa bermakna kegelapan, sesuatu yang kelam, kematian, energi negatif, atau bahkan sesuatu yang horor atau menakutkan. Jenis huruf Arial Bold yang digunakan melambangkan kesederhanaan, sikap lugas, modern, dan futuristik. Penggunaan warna putih pada font ini menunjukan seolah tulisan ini 'ingin mencuri perhatian' ketika dipadukan dengan warna latar hitam. Dalam unsur visual ini, prinsip kontras (gelap-terang) digunakan dalam desain ini. Tujuannya adalah untuk menonjolkan informasi dan membantu meningkatkan nilai keterbacaannya. Penggunaan warna hitam dalam label ini bisa jadi penunjang kesatuan dari seluruh unsur visual dalam peringatan ini, karena warna hitam juga identik dengan maskulinitas atau kelelakian, dimana umumnya konsumen rokok adalah kaum pria. Dengan menggunakan unsur ini, tentu saja aspek kedekatan makna secara psikologis juga bisa digunakan untuk menyampaikan pesan. Dari sisi jenis huruf atau font, yang digunakan adalah Arial. Jenis huruf ini termasuk dalam kategori huruf Sans Serif atau huruf dengan desain tanpa kait diujungnya. Menurut peneliti, penggunaan jenis huruf ini sangat tepat karena bila menggunakan font yang terlalu artistik dikhawatirkan tulisan isi pesan malah lebih sulit terbaca ata kurang menarik perhatian. 
2. Kolom Label Dengan Tulisan

Merokok Dekat Anak

Berbahaya Bagi Mereka.

Tanda verbal berupa label denagn latar belakang berwarna hitam pekat pada tulisan 'MEROKOK SEBABKAN KANGKER PARU-PARU DAN BRONKITIS KRONIS' selain berfungsi menonjolkan katakata tersebut yang dicetak dengan warna putih juga dapat dimaknai berdasarkan respon psikologis yang ditimbulkannya di mana berarti kekuatan, kematian, misteri, dan ketidakbahagiaan. Hal ini berarti informasi kesehatan ini disampaikan secara kuat, mengandung ketidakbahagiaan, dan mengancam di mana kangker paru-paru dan bronchitis kronis adalah akibat bila mengabaikan hal yang diinformasikan.

3. Foto Pria Sedang Terbaring Dengan Bagian Dada Tampak Paru-Paru Yang Menghitam Karna Kangker Dan Bronkitis Kronis

Makna konotatif pada gambar ini adalah pria ini tampak lemah tak berdaya hal ini di tunjukkan dari sikap badan yang terbaring kaku, dan tampak di bagian paru-paru terdapat bercak keabu-abuan yang hampir menutupi semua bagian organ paru-parunya dalam psikologis warna keabuabuan ini bermakna kerusakan atau kehancuran dan kangker paru-paru dan bronchitis kronis ini merupakan ancaman yang berbahaya karna paru-paru merupakan organ tubuh yang sangat penting, organ ini berfungsi sebagai alat pernafasan bagi manusia dan apabila paru-paru telah terserang kangker seperti pada gambar tersebut maka penderita harus menjalani perawatan secara rutin agar bisa tetap bertahan hidup, warna abu-abu ini mengandung arti kerusakan sedangkan merah pucat mengandung arti kelemahan. Pada gambar peringatan "merokok sebabkan kanker paru-paru dan bronkitis akut”, makna pada gambar berupa kanker paru-paru merupakan kanker yang disebabkan oleh rokok jika dikonsumsi secara terus menerus. Kanker Paruparu” merupakan penanda yang konsep mentalnya, penyakit yang menjangkiti bagian tubuh tertentu pada diri seseorang atau dalam hal ini bersamayam dan menyerang paru-parunya, tergantung dari pemahaman seseorang tentang kata "Kanker Paru-paru" tadi. Sedangkan kata "Bronkitis Kronis” mendatangkan petanda peyakit yang gejalanya menyebabkan penderitanya mengalami masalah pernafasan akut. Kata "Kanker Paru-paru" dipakai untuk memberikan keterangan kepada audiens bahwa apa yang mereka lihat adalah suatu kondisi yang menimpa seseorang pada organ dalam tubuhnya karena mengidap penyakit ini. Gambaran ini juga dipakai untuk mewakili penyakit yang disebut bronkitis karena diketahui jenis penyakit ini juga menyerang saluran pernapasan dan paru-paru. 
c. Analisis Makna Mitos Pada Gambar Merokok Sebabkan Kangker ParuParu Dan Bronkitis Kronis.

Gambar diatas adalah organ dalam tubuh manusia yakni paru-paru, paru-paru merupakan alat pernafasan manusia. Pada gambar paru-paru diatas tampilannya jauh berbeda pada paru-paru manusia pada umumnya yakni dalam segi warna jika dibandingkan dengan paru-paru manusia normal paru-paru mereka cenderung berwarna kemerahan. Tetapi pada gambar paru-paru diatas warnanya hitam keabuan, paru-paru diatas adalah paru-paru yang telah terserang penyakit kangker. Dari gambar ini kita dapatkan kalimat "Merokok Sebabkan Kanker Paruparu Dan Bronkitis Kronis” tanda verbal ini menggunakan kode narasi di seluruh kalimat pada uraian merokok, gambar ini memberitahukan jenis kegiatan atau aktivitas merokok yang dikerjakan, akan sebabkan kanker paru-paru dan bronkitis kronis. Kalimat ini mendukung apa yang dikatakan sebelumnya tentang "Kanker Paruparu Dan Bronkitis Kronis” yang diperingatkan pemerintah. Dengan peringatan ini harapan pemerintah mampu memberikan pengaruh pada perokok aktif maupun perokok pemula sehingga mampu menekan tingginya angka perokok di Indonesia dan mengurangi serta mencegah penderita kangker paruparu dan bronkitis kronis.

\section{Pembahasan}

Penelitian ini bertujuan untuk mengetahui makna yang terkandung di dalam gambar peringatan kesehatan pada kemasaan rokok berdasarkan peraturan menteri kesehatan No 28 Tahun 2013. Makna yang dimaksud dalam penelitian ini adalah makna denotasi, konotasi serta mitos seperti yang diungkapkan Roland Barthes dalam teorinya. Dalam penelitian ini terdapat lima gambar yang di analisis menggunakan analisis model semiotika Roland Barthes. Gambar-gambar tersebut diantaranya adalah gambar merokok sebabkan kangker mulut, gambar merokok membunuhmu, gambar merokok sebabkan kangker tenggorokan, gambar merokok dekat anak berbahaya bagi mereka, serta gambar merokok sebabkan kangker paruparu dan bronkitis kronis. Sesuai dengan tujuan penelitian maka hal yang akan di bahas antara lain:

\section{Makna Denotatif}

Denotasi adalah tingkat pertandaan yang menjelaskan hubungan penanda dan petanda pada realitas, menghasilkan makna eksplisit, langsung, dan pasti atau dengan kata lain denotasi adalah apa yang di gambarkan tanda terhadap suatu objek. Dari hasil penelitian menunjukkan bahwa kelima gambar dalam peraturan menteri kesehatan No 28 Tahun 2013 memiliki makna denotatif yang berbeda-beda, hal tersebut sesuai dengan tampilan masing-masing gambar.

Gambar merokok sebabkan kangker mulut gambar ini menampilkan tuliasn "peringatan dan merokok sebabkan kangker mulut” serta menampilkan bentuk mulut yang penuh luka menjijikkan.

Gambar merokok

membunuhmu gambar ini menampilkan tuliasn "peringatan dan merokok membunuhmu" disertai gambar seorang pria yang sedang merokok dengan asap yang mengepul dan di damping oleh dua buah tengkorak.

Gambar kangker tenggorokan gambar ini menampilkan tulisan "merokok sebabkan kangker tenggorokan" disertai gambar tenggorokan yang berlubang dengan benjolan merah dan luka pada area leher. 
Gambar merokok dekat anak berbahaya bagi mereka gambar ini menampilkan tulisan "peringatan dan merokok dekat anak berbahaya bagi mereka” disertai gambar seorang pria yang merokokdengan asap yang mengepul dengan menggendong anak kecil.

Gambar merokok sebabkan kangker paru-paru dan bronchitis kronis menampilkan tulisan "peringatan dan merokok sebabkan kangker paru-paru dan bronkitis kronis" disertai gambar paru-paru yang menghitam akibat endapat asap rokok.

\section{Makna Konotatif}

Konotasi adalah istilah yang digunakan Barthes untuk menunjukkan signifikasi tahap kedua. Hal ini menggambarkan interaksi yang terjadi ketika tanda bertemu dengan perasaan atau emosi dari suatu objek. Dari hasil penelitian menunjukkan bahwa makna konotatif dari lima gambar dalam peraturan menteri kesehatan No 28 Tahun 2013 memilikai makna konotatif yang berbeda-beda sesuai dengan gambar yang di tampilkan..

Gambar merokok sebabkan kangker mulut gambar ini menampilkan efek yang di timbulkan akibat merokok karna rokok pada dasarnya mengandung zat-zat kimia berbahaya yang dapat menyebabkan kangker, sehingga peringatan dalam bentuk gambar di sertai dengan tulisan ini memberikan makna konotatif larangan keras untuk mengkonsumsi rokok karna dapat menyebabkan kangker mulut.

Gambar merokok membunuhmu gambar ini menampilkan gambar yang di sertai tulisan, tulisan tersebut memberikan peringatan dan penjelasan gambar peria yang sedang merokok dengan asap yang mengepul dan di damping dua buah tengkorak di samping perokok. Gambar ini mengandung makna konotatif bahwa merokok merokok lebih cepat membuat seorang kehilangan nyawa. Ilustrasi dua buah tengkorak memberikan pesan kematian yang selalu mengintai pengkonsumsi rokok.

Gambar merokok sebabkan kangker tenggorokan, gambar yang disertai tulisan ini menampilkan gambar tenggorokan yang berlubang dan luka yang mengerihkan di area sekitar tenggorokan gambar ini adalah gambar efek yang di timbulkan akibat merokok yang mengandung makna konotatif peringatan keras bagi para perokok karena merokok hanya akan membuat seorang terserang penyakit berbahaya seperti kangker tenggorokan.

Gambar merokok dekat anak berbahaya bagi mereka dalam gambar ini terdapat tulisan peringatan dan keterangan gambar merokok dekat anak berbahaya bagi mereka tulisan ini mengingatkan kepada perokok dan memberikan ketegasan pada gambar bahwa efek merokok di dekat anak sangat membahayakan kesehatan anak dan berpengaruh kepada pertumbuhanya juga, karna pada dasarnya anak-anak masih memiliki fisik yang rentang.

Gambar merokok sebabkan kangker paru-paru dan bronkitis kronis, gambar ini menampilkan tulisan peringatan di sertai penjelasan gambar kangker paruparu yang menghitam akibat endapan asap rokok yang mengandung makna konotatif larangan kepada perokok untuk segera meninggalkan rokok agar tidak mengalami efek seperti pada gambar tersebut.

3. Makna Mitos

Mitos adalah unsur terpenting yang dapat mengubah sesuatu yang kultural atau historis menjadi 
alamiah dan mudah di mengerti. Mitos bermula dari konotasi yang telah menetap di masyarakat, sehingga pesan yang didapat dari mitos tersebut sudah tidak lagi di pertanyakan oleh masyarakat. Kebiasaan merokok merupakan hal yang buruk dan harus di tinggalkan selain menyebabkan penyakit berbahaya seperti kangker tapi juga dapat menyebabkan kematian selain itu merokok juga membahayakan orang di sekitar perokok karna perokok pasif lebih banyak menghirup asap yang mengandung zat kimia yang lebih tinggi.

Dari kelima gambar yang terdapat pada kemasan rokok sesuai gambar peringatan kesehatan berdasarkan Peraturan Pemerintah No 28 Tahun 2013 mengandung makna mitos bentuk ancaman kepada perokok atas dampak yang terjadi agar segera meninggalkan kebiasaanya dan lebih peduli terhadap nyawa dan kesehatannya.

\section{PENUTUP}

Kesimpulan penelitian ini sesuai dengan permasalahan yang telah di bahas pada bab-bab sebelumnya yaitu mengenai "Representasi Gambar Peringatan Kesehatan Pada Kemasan Rokok dengan menggunakan Analisis Semiotika Roland Barthes Berdasarkan Permenkes No 28 Tahun 2013”. Berdasarkan peraturan pemerintah ini terdapat lima gambar yang wajib di patuhi dan di terapkan pada kemasan rokok oleh perusahaan rokok. Adapun kelima gambar tersebut adalah gambar merokok sebabkan kanker mulut, gambar merokok membunuhmu, gambar merokok sebabkan kanker tenggorokan, gambar merokok dekat anak berbahaya bagi mereka, serta gambar merokok sebabkan kanker paru-paru dan bronkitis kronis. Kemudian Selanjutnya sesuai dengan tujuan penelitian ini yaitu untuk mengetahui makna denotatif, konotatif dan mitos berdasarkan peraturan pemerintah
No 28 Tahun 2013 maka dapat di simpulkan sebagai berikut:

1. Makna Denotatif

Makna denotatif dari kelima peringatan kesehatan bergambar berdasarkan peraturan pemerintah No 28 Tahun 2013 adalah bentuk peringatan berupa gambar-gambar yang mengerihkan yang di sebabkan akibat mengkonsumsi rokok. Seruan tentang akibat dan tampilan dari gejala yang ditimbulkan penyakit berbahaya ini yang pertama adalah kangker mulut di ketahui pada gambar kangker mulut ini tanpak luka di bagian bibir yang menjijikkan dan ini menunjukkan luka yang serius. yang kedua adalah merokok membunuhmu seperti yang tampak pada gambar orang yang merokok dan tengkorak di belakangnya yang menandakan bahwa merokok mendekatkan pada kematian, yang ketiga adalah gambar kangker tenggorokan tapak pada gambar tenggorokan yang berlubang di sertai benjolan merah pada luka yang sangat mengerihkan,yang ke empat adalah merokok dekat dengan anak berbahaya bagi mereka tampak pada gambar ini anak kecil yang di dan marabagendong oleh peria yang sedang merokok dengan asap yang begitu banyak yang akan membahayakan kesehatan pada si anak tersebut, yang kelima adalah merokok sebabkan kangker paruparu dan bronchitis kronis tampak pada gambar ini paru-paru yang menghitam yang hampir menutupi organ paru-paru akibat mengkonsumsi rokok.

\section{Makna Konotasi}

Makna konotasi muncul dalam gambar yang di terapakan sesuai peraturan pemerintah No 28 Tahan 2013 adapun karakter yang mewakili simbol-simbol, historis serta berkaitan dengan emosional yang mengarah pada kondisi sosial budaya 
dan emosional personal, Maka secara umum penyampaian sisi dampak buruk bagi kesehatan yang disebabkan merokok yang ditonjolkan berhasil memberikan makna konotasi bahwa mengabaikan pentingnya peringatan dan seruan tentang penyakit berbahaya akibat merokok akan menyebabkan kangker mulut, kematian, kangker tenggorokan, beresiko tinggi membahayakan orang di sekitar perokok (perokok pasif), serta kangker paru-paru dan bronkitis kronis.

\section{Mitos}

Pada tahap mitos ini didapat dari memaknai petanda konotasi. Dengan kata lain mitos adalah makna dari makna konotasi yang mendalam. Peneliti mengidentifikasi mitologi yang beroperasi dalam gambar peringatan kesehatan tersebut yaitu, penyakit berbahaya seperti kanker dapat dengan mudah muncul dan menyerang perokok karna didalam rokok mengandung zat-zat kimia yang sangat berbahaya. Pembuat gambar peringatan juga menanamkan mitos bahwa dampak buruk rokok tidak hanya berlaku bagi perokok itu sendiri namun juga bagi orang atau anak yang berada cukup dekat untuk menghirup asap yang ditimbulkan rokok (perokok pasif). Selain itu pembuat gambar peringatan kesehatan berusaha menanamkan ideologi bahwa setiap perokok beresiko lebih besar kehilangan nyawa lebih cepat dibanding mereka yang tidak merokok. Akhirnya dari kelima gambar peringatan kesehatan dapat disimpulkan bahwa mitos yang terbentuk adalah bentuk ancaman kepada perokok atas dampak yang terjadi agar segera meninggalkan kebiasannya dan lebih peduli terhadap nyawa dan kesehatannya.

\section{Saran}

Sehubungan dengan penelitian ini saran yang dapat penulis berikan adalah sebagai berikut:

1. Bagi pemerintah, peneliti melihat bahwa gambar peringatan kesehatan dalam Permenkes No. 28 Tahun 2013 telah menunjukkan besarnya resiko yang di sebabkan akibat merokok, hal ini karena selain pencantuman pesan dan informasi berupa teks, peringatan kesehatan juga menyertakan visual atau gambaran nyata dari pesan yang disampaikan. Akan tetapi hasilnya belum maksimal, untuk itu pemerintah perlu memperbaharui peringatan kesehatan dengan menyertakan hasil survey dari Kementrian Kesehatan tentang jumlah penderita penyakit dan kematian yang disebabkan akibat merokok.

2. Bagi masyarakat, agar dapat dijadikan wawasan dan ilmu tentang pentingnya penggunaan tanda terhadap pemaknaan suatu pesan. Selain itu, penulis juga mendorong masyarakat agar lebih kritis terhadap kebijakan pemerintah terutama yang berkaitan dengan penyampaian pesan peringatan kesehatan karena bisa saja terjadi kekeliruan dalam pembuatannya yang bila dicermati justru berpeluang memberikan dampak sebaliknya dari tujuannya semula.

Bagi penelitian yang akan datang, hasil penelitian ini diharapkan dapat dijadikan sebagai dasar pengembangan penelitian di masa mendatang dengan menggunakan pemikiran semiotika yang serupa, ataupunmenggunakan pemikiran semiotika lain. Selain itu, penelitian serupa juga bisa dilakukan dengan menggunakan metode yang berbeda, misalnya dengan menggunakan metode kuantitatif yang akan mengungkap temuan yang lebih komprehensif dan dapat digeneralisir. 
DAFTAR PUSTAKA

Berger, Asa, Artur, 2000. Tanda-Tanda Dalam Kebudayaan Kontemporer, Yogyakarta: PT. Tiara Wacana Yogya.

Hoed, H, Benny, 2014 "Strukturalisme, Pragmatik, dan Semiotik Dalam Kajian Budaya” dalam Indonesia: Tanda yang Retak, Jakarta: Wedatama Widya Sastra.

Cobley, Paul dan Jansz ,Litza, 2002. Mengenal Semiotika For Beginners Di Terjemahkan Oleh Sukono, ciptadi Dari Semiotic For Begeners, Bandung: Mizan.

Hoed, H, 2004. Strukturalisme Pragmatik Dan Semiotik Dalam Kajian Budaya, Indonesia Tanda Yang Retak, Jakarta: Wedatama Widya Sastra.

Nainggolan, Tigor, Azas, 2016. gambar dan tulisan peringatan kesehatan pada kemasan produk tembakau yang ada saat ini masih belum efektif untuk menurunkan apalagi menekan jumlah pengkonsumsi rokok di Indonesia, Jakarta.

Patton, Quinn, Michael, 2007. Metode Evaluasi Kualitatif, Yogyakarta: Pustaka Pelajar.

Piliang, Amir, Yasraf,1998. Sebuah Dunia Yang Dilipat, Realitas Kebudayaan Menjelang Milenium Ketiga Dan Matinya Posmodernisme, Bandung: Mizan.

Supriono, Racmat, 2010. Desain Komunikasi Visual, Yogyakarta: Andi

Sobur, Alex, 2006. "Analisis Teks Media“Suatu Pengantar Untuk Analisis Wacana, Analisis Semiotika Dan Analisis Framing”, Bandung: PT. Remaja Rosdakarya.

Sobur, Alex, 2009. Semiotika Komunikasi, Bandung: PT. Remaja Rosdakarya.

Singarimbun, Marsi, 1989. Metode Penelitian Survey, Jakarta: LP3LS.

Sobur, Alex, 2004. Analisis Teks Media Suatu Pengantar Untuk Analisis Wacana Analisis Semiotika Dan Analisis Framing”, Bandung: PT. Remaja Rosdakarya.
Supriyono, (2010.:131) body copy diartikan sebagai pengurai informasi suatu produk secara detail sehingga di harapkan dapat- membujuk dan memprovokasi pembaca untuk membeli produk. Panjang pendeknnya body copy tergantung kebutuhan dan kondisi ruang (ukuran) iklan.

Singarimbun Marsi, 1989. Metode Penelitian Survay, Jakarta: LP3LS.

Sobur Alex, 2004. Analisis Teks Media: Suatu Pengantar untuk Analisis Wacana, Analisis Semiotik dan Analisis Framming, Bandung: PT. Remaja Rosdakarya.

Tinarbuko, Sumbo, 2009. Semiotika Komunikasi Visual, Yogyakarta: Jala Sutra.

Wibowo, 2011. Semiotika Aplikasi Praktis Bagi Penelitian Dan Sekripsi Komunikasi, Jakarta: Mitra Wacana Media.

\section{Sumber Lain:}

Peraturan Pemerintah Republik Indonesia Nomor 109 Tahun 2012, Tentang Pengamanan Bahan Yang Mengandung Zat Adiktif Berupa Produk Tembakau Bagi Kesehatan.

Peraturan Menteri Kesehatan Nomor 28 Tahun 2013, Tentang Pencantuman Peringatan Kesehatan dan Informasi Kesehatan pada Kemasan Produk Tembakau.

\section{Sumber Website:}

(http://www.bprs.kemkes.go.id.pdffiles, di akses tanggal 23 Juli 2017 Pukul 9:10 Wib).

(http://www.Peraturan Pemerintah No 109 Tahun 2012. Diakses pada 5 September 2017 Pukul 15:07)

(http:www.harianterbit.com, di akses tanggal 25 juli 2017 Jam 16:23).

(http://www.101.255.58.243/files/refobiro/ integritas/Permenperin_No.63_2015 _1.pdf. diakses pada 6 September 2017, Pukul 20:22). 